\title{
Give the Screw Another Turn-A Cultural Re-Reading of the Turn of the Screw ${ }^{l}$
}

\author{
Weiqiang Mao \\ School of Foreign Languages, Jiangsu University, 212013 Zhenjiang, China \\ E-mail: mcatalpa@ujs.edu.cn
}

\begin{abstract}
Henry James' novel The Turn of the Screw is notorious for its ambiguous nature about the ghostly figures that keep haunting the protagonist the governess. This paper attempts to give the study of this novel another turn of the screw by arguing that it is a hybrid of popular culture of ghost stories and high culture of psychological studies of ghosts. It is intended by Henry James as a blueprint for the development of American culture.
\end{abstract}

Index Terms - ghost story, ghost studies, cultural hybridity

\section{INTRODUCTION}

The publication of Henry James's novel The Turn of the Screw in 1898 turned out to be a success for an author who was then caught in a dilemma that both taxed his fame and his pocket. The novel aroused at once great curiosity and interest among the public for its gothic flavor, and initiated in the meantime a seemingly endless debate among critics. It relieved to some extent the suffering afflicted on Henry James by the failure of his first play Guy Domville, which brought an end to the trial of his hands on the theatre (Simpson). ${ }^{2}$

Over the past century, The Turn of the Screw has seen great efforts made to probe into the truth most critics believe Henry James has embedded within it. After a close analysis of all the essays referred to by Parkinson in his "The Turn of the Screw: A History of Its Interpretations 1898-1979", we will find a controversy constantly at work across the critical history of The Turn of the Screw: critical opinions concerning the novel divided along the apparitionist and non-apparitionist line.(Seymour XI-XII) ${ }^{3}$ Most critics started their discussion from just one side of the line either to argue for or against the nature of the ghost in The Turn of the Screw. It is a practice that has fallen for the trap set by Henry James in the novel "only for the unwary (readers)" (NEC 1). It calls then further reading to bring out the whole truth lying behind the effects The Turn of the Screw is capable to create.

To the intention of writing The Turn of the Screw, James has been noticed of making more than one allusion. When it first appeared in 1898, James claimed it as "a ghost story to depart altogether from the rules" (NEC xix-xx). But later he lamented elsewhere that The Turn of the Screw was "something I have supposed to be a subject (but) turns out to be none" (quoted from Parkinson). In a letter to H.G. Wells, James implied that this novel was "essentially a pot-boiler and a jeu d'esprit in which he had delighted in manipulating the reader's literary and moral sensibilities." (Seymour IX) ${ }^{4}$ Obviously, there exists in James's statements about his intention an inconsistence, which, Parkinson points out, only intensified the controversy along the apparitionist and non-apparitionist line. Therefore, critical appreciation of The Turn of the Screw shouldn't be limited to the immediate sources related to the novel. Instead, it should be put within the entire canon of Henry James's oeuvre.

Due largely to his international themes and his contribution to Modernism, Henry James is regarded as the "beacon of high culture" (Blair 3). His relation to high culture manifests itself in two levels. First, he is seen throughout his life to write novels that he considered a "high art form" belonging to high culture (Hale 80). Second, he has expressed an unmistakable concern for high culture in his novels of international themes. For James, American culture was barbaric that it prevented Americans from appreciating his fine arts. As a result, he twice expatriated himself from America to Europe to seek for a cultural shelter that would both accommodate his cultural pursuit and provide a cultural audience that would appreciate his fine arts. But recently, Sara Blair contends, "rather than being paraded as a beacon of high culture, James actually expresses a nuanced understanding of, and engagement with, popular culture" (Blair 3). It is most evident in his writings of ghost stories that were popular in the latter part of the $19^{\text {th }}$ century. They were written to

\footnotetext{
1 This research is financed by "Teaching and Reform Program of Jingjiang College, Jiangsu Univerisity, China” (JJ08C034) “Teaching and Reform Program of Jiangsu University" (JGYB2009076), and Jiangsu Government Scholarship for Overseas Studies

2 Guy Domville became a nightmare for Henry James. On the disastrous opening night of the applause of James's friends was drowned out by the jeering of an audience that wanted incident and emotion, not anemia in three acts. After this fiasco, James reconsecrated himself to fiction.

${ }^{3}$ For example, Wilson's 1952 article "The Ambiguity in Henry James" suggested that James' governess is a classic psycho-neurotic Freudian case, which initiated the on-going battle between "scientific" and "imaginative" readings of the narrative. The apparitionist, who include Leon Edel, Allen Tate and Robert Heilman support the governess ghostly encounter with the ghost from the tower.

4 Form "pot-boiler", we can easily notice James' great eager to earn the money profit brought about by a large audience created by the popular culture..
} 
win the popular audience that his Guy Domville had turned away.

Henry James' involvement in culture has gained wide recognition among critics of cultural concerns. Some scholars, Dai Xianmei, for instance, argued that Henry James proposes in his works a blueprint for the development of American culture (2004). Revisionist critics in the past have exaggerated James' involvement in popular culture. But recently scholars like John Carlos Rowe and Richard Salmon tried to strike a balance between Henry James' desire for and his resistance to popularity.(Daugherty 99) In other words, cultural critics of Henry James in the last two decades tend to focus on his novels of international themes, leaving works of other themes much intact. In the following part, this paper attempts to study The Turn of the Screw both as product of popular culture and a product of high culture, with the ambition to reconcile the two sides of the controversy that dominates the critical appreciation of the novel for nearly a century.

\section{The TURN OF THE SCREW AS A POPUlar GHOST STORY}

It is first of all intended by Henry James as a popular ghost story to speak out the unspeakable unspoken past. ${ }^{3}$ Critics of the apparitionist view hold that The Turn of the Screw is a ghost story and what the Governess tells us is true; whereas the non-apparitionists contend that the Governess is insane and what she sees is simply her hallucination. As has been argued earlier, both the apparitionist and non-apparitionist critics have fallen for the "trap" set by Henry James within the novel. An examination of the social and cultural context from which The Turn of the Screw arose will enable us a better understanding of the nature of the ghosts and Henry James' true concern in the writing of this novel.

In spite of the inconsistence within the statements about the genre of The Turn of the Screw, James insists anyway that it is a ghost story, though it falls short of his original expectation. His belief that he was composing a ghost story could find its justification in two reasons. The first one has been his personal involvement in the writing of ghost stories before he started the writing of The Turn of the Screw. The other reason concerns the dilemma in which he was still caught when he started to compose the novel. He hoped that a story like The Turn of the Screw, if it turned out successfully, would relieve him of the mental and economical uneasiness. It was due largely to these two reasons that Henry James went all out to practice what he would have called "low forms of art".

Given a further analysis, the two reasons mentioned above turn out to be the very social and cultural context that occasioned the appearance of The Turn of the Screw. When his failure in Guy Domville (1895) completely dashed his hopes both to win the popular audience and to earn the money he badly needed to pay for the Lamb House, Henry James "continued his writing of short stories before he crawled back to his literary canon (of novels of international theme) "(quoted from Raw 243) Among the short stories were some ghost stories, which were "both a continuation and a development of the gothic novels that were still in vogue in the Victorian period" (Wolfe 68). The growth of popular magazines around the end of the nineteenth century "increased the proliferation of ghost stories among the working class" (Poupard 207-208). Stories written in gothic traditions, namely those describing strange happenings to victims, governesses and mistresses in particular, in grotesque surroundings constituted constant appealing to the enlarging reading groups. Any ghost story, if it was popular with the general public, could then both establish an author's name and bring about a tremendous income. To the money value of ghost stories, Henry James himself refers to it in the preface to The Turn of the Screw as the "sad drop ... in the general quality of such commodities" (James, xv). The practice of writing ghost stories at the turn of century was then both inevitable and necessary for a writer like Henry James who wanted both to restore his name and to make a fortune to ease his financial problems. Written within such a social and cultural context, James's The Turn of the Screw should be read as a ghost story that is a product of popular culture.

In fact, Henry James's The Turn of the Screw not only constitutes part of the popular culture of ghost stories, but also actively participates in the public flavor for the ghost stories. In the Victorian age, it was a common cultural practice to tell ghost stories among friends and family members by fireside at night, especially on Christmas Eve (Bleiler 1-16). In the prologue to The Turn of the Screw, we find a group of friends sitting around fireplace on Christmas Eve telling and listening to ghost stories. So this scene initiates and imitates on a minor scale the cultural practice of the age. On the other hand, the structure of The Turn of the Screw, which is a story thrice retold form the original i.e. first from the Governess to Douglass, then from Douglass to the anonymous narrator in the prologue, and finally from the anonymous narrator to the reader, makes an imitation of the cultural practice of ghost story telling on a larger scale.

Whereas, so far as the source of The Turn of the Screw is concerned, we will find that Henry James gives the ghost story telling practice another turn of the screw. Henry James has professed to owe a great indebtedness to Archbishop Benson for the source of the novel but Archbishop Benson's sons denied any tale in their father's treasure similar to The Turn of the Screw. Instead, critics, B. Cargill for instance, find The Turn of the Screw similar to several other ghost stories of earlier times (Parkinson). Therefore, Henry James's ghost story in The Turn of the Screw is possibly a retelling of past ghost stories. But his story is different from the earlier ones in that his version makes "a departure from the rules" of the conventional ghost stories (James xv). This departure is most obvious in the fact that his version is so different form Archbishop Benson's that people fail to recognize the original from which Henry James has drawn sources. On the other hand, he has developed and refined the techniques of telling that his ghosts, Virginia Woolf once observed, "have nothing in common with the violent old ghosts--the blood-stained sea captains, the white horses, the headless ladies of dark lanes and windy commons"(quoted form Parkinson ). Most importantly, The Turn of the Screw 
picks up the gothic tradition of victimizing governesses. The governess in The Turn of the Screw "fits well into the stereotypes people constantly find in gothic fictions like Jane Eyre, Rebecca and A Sicilian Romance"(Smith 1-7). Consequently, The Turn of the Screw is an extended and highly literary ghost story retold.

Retelling plays a significant role within The Turn of the Screw. In the novel, the Governess is noted by the anonymous narrator to retell in her manuscript her past experience of encountering ghosts from her memory: "The first of these...that the written statement took up the tale at a point after it had, in a manner, begun"( 6). The retelling of past experiences is most evident in the words the Governess carefully chooses to express every touch of her experience, among which are "I remember"( 9), "I recollect" (16), “as I recall”(18), etc, to mention just a few. To tell the past experience from present gives the Governess an opportunity to grapple with the meaning by negotiating with the past events. Therefore, the narrative technique of this kind lends a great authenticity to, rather than refuted by many critics as undermine the objectivity of, what was happening in the past.

As it turns out in The Turn of the Screw, we find the recounting of past experiences from a later period of time by the Governess is not influenced at all by her later findings of something horribly strange and shocking. No distortion is made in her account of the stranger she has met for two times before Mrs. Grose, the housekeeper at Bly tells her the stranger she is describing is the ghost of a former valet to the Master.

The Governess's reliability in her account of the story is first evidenced by her enjoying the scenery of Bly, a big old house surrounded with groves with a pair of towers of "gingerbread antiquity" and "architectural absurdities" (20). The prologue that the novel is a ghost story will enable listeners of gothic fiction tastes to recognize that the environment the Governess is accounting is just the one often appears in fiction of gothic traditions. The knowledge of this kind will give the reader an insight to recognize at once the sublime instead of the beauty of such gothic setting at Bly (Carson 255). From The Turn of the Screw, we can find with certainty that the Governess is a gothic fiction lover who has already read classic gothic novels like The Mysteries of Udolpho, Jane Eyre and Amelia. Her familiarity with supernatural happenings related to gothic scenes does not alarm her of the horrifying "secret" (21) at Bly from the start. Instead, the governess takes delight in imagining the surroundings of Bly as a beautiful scene for romance where, just as Jane Eyre meets Rochester, she would have the same romantic encounter with her Master: "it would be as charming as a charming story suddenly to meet some one (I love)" (19). Clearly, the Governess's account of Bly is not influenced by her subsequent horrifying findings at Bly. It would otherwise be a scene for unspeakable "secret" of horror, a thought only hinted at after she encounters for the first time the stranger identified later by Mrs. Grose as the ghost of Peter Quint (22).

Similarly, the Governess makes a reliable account of the stranger before she learns that he is a ghost. The Governess's account of her encounter with him for the first two times lacks the effects and forces generated by ghosts. When she sees him on top of a tower staring at her, her uneasiness is simply caused by her view that "an unknown man in a lonely place is permitted object of fear to a young woman privately bred" like her (20). For the first time, she only detects in him "a touch of strange freedom... in the sign of familiarity of his wearing no hat" (21). For the second time, she only sees him looking through the glass as if looking for something, with no feeling of horror and terror created by ghosts. It is clear that no distortion is made in her early account of the appearance of the stranger.

Therefore, it is justified to say that what the Governess is accounting is reliable and the ghosts are real happenings to her, rather than her daydreaming or hallucination. As she declares later when she is writing from her memory that "I saw him as I see the letters I form on this page" (21). ${ }^{5}$

As has stated earlier, the Governess's story is revealed through retelling: first from her own memory, then through Douglass's memory of the story told to him by the Governess and his reading of the manuscript composed by the Governess of her story, and finally from the anonymous narrator's memory of listening to Douglass's telling and his own reading of the manuscript that Douglass gives him with confidence. The reading experience of The Turn of the Screw is then actually the reading of the Governess's past experiences possessed by the ghosts of Peter Quint and her predecessor Miss Jessel. Therefore, it is safe to say that the ghostly apparitions are summoned up in the retelling of past experiences.

The past in The Turn of the Screw is ailing and unspeakable. It appears for the Governess "the shadow of something" (33). From the prologue to the novel, we find Miss Jessel's death unexplained. Shortly after the Governess arrives at Bly, she receives a letter telling that Miles is dismissed from school but no reason is given. When the Governess finds that Miles is "something divine... with great sweetness of innocent curiosity", she is completely bewildered about the past at Bly. Maybe, there is at Bly a past that nobody wants to mention it because it is ailing. When the Governess sees the stranger for the first time, she wonders: "Was there a 'secret' (past) at Bly"? Based on the relationship between the appearance Peter Quint's ghost and the Governess's admitted thought that there is secret past at Bly when she is retelling her feeling about her first encounter with the ghost at a later time, we can conclude that the ghosts in The Turn of the Screw are in fact an unspeakable past unspoken vying for presence.

Various incidents in the story reveals that the ghosts of past are present with Flora and Miles. When Quint appears for the second time, the Governess finds Flora missing from her bed. As it turns out in the novel, she is simply hiding

\footnotetext{
${ }^{5}$ Douglas relates in the Prologue that her record of employment after the events at Bly was exemplary, and finally that the sudden death of an otherwise healthy young boy can only be accounted for by the fact that he was truly 'possessed', which means that the ghosts are really happenings.
} 
behind the curtains watching the ghost (49). At another time, the Governess finds Flora missing again from her bed when she wakes up in the midnight. Then she finds that Flora "squeezed in behind the blind and was peering out in to night" (51). Later on, she finds Miles playing outside. Obviously the two children share an eerie past with the two ghosts, who as we find were great friends for the two children when they were alive. But they never "allude to either of their old friends", and they are "steeped in their vision of the dead restored to them" (57).

Believing that the ghosts have a plan to take the children, the Governess decides to confront the ghosts of the past. In The Turn of the Screw, we can see an inquisitive governess who is seeking to bring out the secret past at Bly. When Mrs. Grose identifies the stranger she has seen twice as the ghost of Peter Quint, the Governess presses for more about Quint's past through her exquisite skills of conversation (26-33). Her incessantly inquisition about the ghostly past is best exemplified when she tells Mrs. Grose that she has seen Miss Jessel and presses for the information about Miss Jessel:

"Oh, handsome---very very," I insisted; "wonderfully handsome. But infamous."

$\ldots$

"I appreciate," I said, "the great decency of your not having hitherto spoken; but the time has certainly come to give me the whole thing." She appeared to assent to this, but still only in silence; seeing which I went on: "I must have it now. Of what she did? Come, there was something between us." (38-39)

Obviously, each appearance of the ghosts is used by the Governess to seek out the unspeakable unspoken past at Bly.

But the Governess' heroic act goes too far. She develops a "joy in the extraordinary flight of heroism" (Parkinson). The past is so ailing that both Miles and Flora want to repress it in their memory, as a result they never mention it in the Governess's presence. When they are confronted directly by the Governess for the revelation of their ghostly past, Flora goes mad and Miles dies. Therefore, the Governess fails to fulfill her role as a guardian, for which she has had a high opinion. She fancies if she does her job well, the Master will approve her and possibly love her. So her stay in Bly actually turns out to be traumatic experiences.

Through the telling and writing of her experiences, the Governess can trace the origin for the tragedy at Bly. As she recognizes, it is her "joy in the extraordinary flight of heroism" that devastates and destroys the two children, though they might have been polluted by her predecessor and Quint. In this way, the Governess can finally come to terms with the unspeakable unspoken past.

\section{The Turn OF THE SCREW AS A Product of High Culture}

The Turn of the Screw serves at the same time as a report of psychological investigation into human insanity and hallucination that had aroused great interest among some elites of Henry James' time. As has been argued earlier, The Turn of the Screw can be read as a ghost story which is a product of popular culture. But that shouldn't be the end of the story. The reading yet calls another turn of the screw if we are to bring out the truth. When we put the story within another cultural context, we will find it is in the meantime a product of high culture created by Henry James as a "beacon of high culture". It is created not only to meet the popular tastes for ghost stories at the turn of century, but also to attract readers of the elitist few.

The other cultural context worthy of investigation is the intellectual climate in which The Turn of the Screw was composed. The latter part of the $19^{\text {th }}$ had seen growing interest in the study of ghosts from clinical, spiritual, and psychological perspectives. It was the mode of the day for the intellectual elites to be involved in the scientific study of ghosts, and various associations had been set up for this purpose, among which were the Ghost Club at Trinity College and the Society for Psychological Research (SPR), to the latter of which Henry James's brother became a member, was a vice president for eight years, and was elected its presidents for 1894-1896. Henry James had been in continual contact with William and had a great friendship with the founding president of SPR Henry Sidgwick, a professor of moral philosophy at Trinity College. Far from being merely related to this high culture of ghost studies, Henry James had an active hand in it. He had once attended the meeting held by SPR to read William James's dissertation. Besides, he had been reported by Edmund Guney and Frederic Myers, another two members of SPR who were also Trinity men, to be "one of the two reporters of psychical phenomena of ghosts, who have obtained the highest reputation as acute and accurate observers of ghosts" (Beidler 77). Planned as a ghost story to "departure from the rules of scientific ghosts" reported to the SPR (quoted from Parkinson), The Turn of the Screw should not be interpreted in isolation with the high culture of ghost studies.

In The Turn of the Screw, we find that Henry James has placed a figure that is related to the scientific studies of ghosts. If we are, to borrow Henry James's words, "wary enough", we will find Douglas is actually familiar with, if not takes part in, the scientific studies. In the prologue, Douglas mentions that he became acquainted with his sister's governess on one of his college vacations: "I was at Trinity and I found her at home on my coming down the second summer" (2). Douglas had met the governess some "forty years" (3) before he read the manuscript in front of the fire. James's frame-story narrator says that he copies the manuscript "much later" (4) when Douglas, near death sends him the handwritten copy the governess has sent to Douglas before her own death. If that "much later" was something like half dozen years, and was shortly before the story was published in 1898, then simple arithmetic suggests that Douglas could have been at Trinity in 1851, when the Ghost Club was established. Being an intellectual elitist of Trinity College himself, Douglas must be familiar with the scientific studies of ghosts of his day. It is possible then that what Douglas is 
telling us is just one of the cases in the scientific studies, whose primary aim was to "give a rational explanation of the supernatural and then officially suppress the ghosts that were part of popular culture" (Carson).

With regard to both Henry James's assured interest and involvement in the scientific studies of ghosts, as well as the fact that he endows the reporter of the Governess's stories with a familiarity with such studies of ghosts, we can regard The Turn of the Screw as a product of high culture of scientific studies of ghosts. With this finding, together with the attitude adopted in scientific studies of ghosts, namely the attitude to view ghosts as hallucination of the insane and the mentally handicapped, we can render a reasonable explanation of some of the incidents in The Turn of the Screw.

First, there come the ghostly apparitions. The ghosts of Bly are in fact unspeakable past unspoken. They are conjured up by the Governess to come to terms with the past. Since the governess is a gothic-fiction lover, we can postulate that ghost figures are borrowed by the Governess from other gothic fictions for her own purpose. After a careful examination, we will find that much similarity exists between the Governess's ghosts and the standard scientific ghosts identified by Peter G. Beidler:

Ghosts appearing to children

Noises in the night

The face at the window

The fixed stare

Precise description

Identifying ghosts

The sad face

The felt presence of ghosts

Ponds, tables, and stairs

A feeling of cold

Cold of winds

Extinguished lights

Selective seeing of ghosts

The upper part of the figure (Beidler 77).

So the relationship between the Governess's ghosts and the scientific ghosts conjured up by the psychologically handicapped can in part suggest that Henry James wants to have his protagonist as a mad girl.

Second, there comes Douglass' unwillingness to talk about the Governess' account of the ghosts. It betrays to some degree the uncanny nature of the Governess's story. On the other hand, it reveals an abnormal relationship between Douglass and the Governess. It is mentioned by Douglass that he is ten years senior of the Governess, and he "liked her extremely" (5). He notes that the Governess is in love, but her love is reserved for somebody else, most possibly for both the Master and Miles. So he is aware that the Governess is mad and imagining the ghosts. His realization of this kind finds its proof in his inconsistence in his words. He first mentions that the story he is going to read will give the previous one another turn of the screw not for terror, but "for dreadful-dreadfulness" and "for general uncanny ugliness and horror and pain"( 4). Then he talks of Bly "not a scene for shudder" (5). This inconsistence in the effect of the story betrays his slyness in hiding the facts. Being familiar with the ghostly cases reported of his day, he believes his friends, most possibly elitist intellectuals like him, will judge that his lover is obvious mad. For this reason, he is unwilling to talk about the story when he is first asked by his friends. Similarly, he intentionally stresses the fact that the Governess is charming and decent: "she was the most agreeable woman I've ever known in her position". (6)

In The Turn of the Screw, the Governess's madness is not only perceived by Douglass as reporter of the story, it is perceived by the other members of the household at Bly. When Miles is confronted by the Governess about what he was doing outside the house on the lawn, he answers that he did it in order to attain her attention and to give her a chance to "think me---for a chance---bad". Whatever other meanings may lie in Miles's words, it is unmistakable that he is aware of the Governess's abnormal love for him and her determination to take hold of him. So on another occasion, Miles protests that he needs more independence and freedom to "see more life" (66).

Mrs. Grose is furious at the Governess's insatiable desire to probe into the past of Bly. By the lake where the Governess professes that she sees Miss Jessel and therefore has reason enough to prove her past vision of the ghosts of Quint and Miss Jessel are real, it turns out for Mrs. Grose a completely delusion of the Governess. Though she is illiterate, Mrs. Grose's innocence cannot prevent her from making the ordinary observation of the nature. So when she finds no image of Miss Jessel as the governess has promised, she "blotted out everything but her own flushed face and her loud shocked protest, a burst of high disapproval: What a dreadful turn, to be sure, Miss! Where on earth do you see anything?" (84) From Mrs. Grose's violent reaction of this kind, we can tell that she is aware of the Governess's insanity as well as her tricks to conjure up the past at Bly.

Of her madness, the governess herself is not altogether unaware. When she later puts down her first encounter with the stranger, she is aware that she is daydreaming about the Master, whom she finds "had never risen, save in a dream or an old novel"(7). So her recognition of her being daydreaming kinds of concedes that the ghost of Peter Quint is simply a hallucination.

To be exact, her madness is purely sexual. As many critics have proved that the tower where she catches sight of Quint for the first time simply reveals her pressed desire for sex. Her desire of this kind shows up vividly in her 
statement about her confrontation with Miles about his sneaking outside at night. When she drops down to Miles bed, she feel a sense of "criminality" and imagines that "he "had' me indeed, and in a cleft ...by the faintest tremor of any overture, I were the first to introduce into our perfect intercourse an element so dire"(55). When she and Miles are taking dinner together after Mrs. Grose takes Flora to the Master's lodging place, the Governess imagines that the two of them are a newly married couple:

We continued silent while the maid was with us---as silent, it whimsically occurred to me, as some young couple who, on their wedding-journey, at the inn, feel shy in the presence of the waiters. (95)

Clearly, the Governess develops a pedophilia for Miles. It is for this strong desire to possess the two Children and have their love that she conjures up the ghosts of Quint and Miss Jessel so as to justify her role to be watchful on them, to protect them form being taken by the ghosts. So when she sees Quint for the last time in the dinning room, she goes all out to protect Miles by taking hold of him firmly. Of course, the ghost of Quint is invisible to Mile, which ultimately enraged him and frightened him. As the governess later remembers, "he was at me in a white rage, bewildered, glaring vainly over the place" (103).

Therefore, through the retelling and writing of her past experience, the Governess is able to realize what has caused the madness of Flora and what has led Miles finally to death. In this way, she can come to terms with the ailing past at Bly and have her abnormal love "come out" (5). As Douglass observes, it is only when her love of this kind comes out that she is able to tell him her story: "That came out---she couldn't tell her story without its coming out" (3)

\section{CONCLUSION}

As the title of The Turn of the Screw suggests, critical readings of the novel should give past interpretations another turn of the screw. Though an author's professed intention cannot be used to explain away the real intention underlying The Turn of the Screw, it reveals nevertheless the author's interest in ghost story as a form of popular culture. After an analysis of Henry James' intention for the creation of The Turn of the Screw and the social and cultural context from which it arises, we find with certainty that The Turn of the Screw is a ghost story. The narrative structure of the novel further reveals its relationship to popular culture. Based on these findings, The Turn of the Screw has every quality to call it a ghost story belonging to the genre of popular culture.

On the other hand, The Turn of the Screw has "raison de plus" (3) to qualify itself to be a product of high culture. Henry James' active involvement in the scientific study of ghosts enables him to make a thorough investigation into the nature of ghosts, the findings of which are then fused into The Turn of the Screw as an artistic re-account of past experiences. For this reason, The Turn of the Screw can clarify the mysteries accumulating around the existence of ghosts and dissipate as a result the superstitious popular opinions (of ghost) around the turn of the century. In this way, "turn" functions as a tool to root out the popular culture and set itself as a mode of high culture.

Written in this manner, The Turn of the Screw can be regarded as a hybrid of low culture and high culture appealing to both popular audience and the elitist few. The hybridization of low culture and high culture in the novel is in consistence with Henry James's cultural concern explicitly expressed in his high art form of novels of international themes.

\section{REFERENCES}

[1] Beidler, Peter G. Ghosts, Demons, and Henry James: The Turn of the Screw at the Turn of the Century. Columbia: University of Missouri Press, 1989.

[2] Blair, Sara. Henry James and the Writing of Race and Nation. Cambridge: Cambridge University Press, 1996.

[3] Bleiler, Everett F. "An Introduction to A Treasury of Victorian Ghost Stories" A Treasury of Victorian Ghost Stories. Ed. Everett F. Bleiler. New York: Charlse Scribners' Sons, 1981.

[4] Carson, James P. "Enlightenment, popular culture, and Gothic fiction." The Cambridge Companion to the Eighteenth-Century Novel. Ed. John Richetti. Cambridge University Press, 1996: 255-276

[5] Dai, Xianmei. "From Rejection to Appreciation: Henry James Studies in China" http://www2.univ-reunion.fr/ ageof/text/74c21e88-589.html

[6] Daugherty, Sarah B. "Henry James” American Literary Scholarship 1 (1998): 99-112

[7] James, Henry. NEC-New York Edition. Vol. XII. New York: Charles Scribners'Sons, 1908.

[8] James, Henry. TS - The Turn of the Screw. New York: Bantam Books, 1983

[9] Hale, Dorothy J. "Henry James and the Invention of Novel Theory" in The Cambridge Companion to Henry James. Ed. Jonathan Freedman. Cambridge: Cambridge University Press, 1998.

[10] Parkinson, Edward J. The Turn of the Screw: A History of Its Critical Interpretations 1898-1979. http://www.turnofthescrew.com/

[11] Poupard, Dennis. Ed. Twentieth Century Literary Criticism. Vol.32. Detroit: Gale Research Company, 1989.

[12] Raw, Laurence. "Reconstructing Henry James: The Heiress" in Literature/Film Quarterly 30 (2000): 243-48

[13] Smith, Andrew. "The Female Gothic: Then and Now" in Gothic Studies, Vol.6. 2004 http://www.manchesteruniversitypress.co.uk/information_areas/journals/gothic/060001.pdf

[14] Simpson, Mona. "Henry James" in Conjunctions. Vol.29 Fall 1997. http://www.conjunctions.com/archive.htm

[15] Seymour, Claire. "General Introduction" The Turn of the Screw \& The Aspern Papers. Wordsworth Classics, 1993.

[16] Wolfe, Charles K. "Victorian Ghost Story Technique: The Case of Henry James" in The Romantist. No.3, 1976: 68- 